\title{
Symbola Caelestis
}

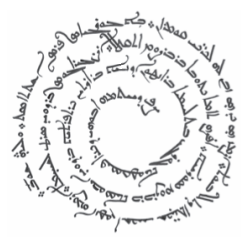




\section{Scrinium: Revue de patrologie, d'hagiographie critique et d'histoire ecclésiastique}

\section{Editorial Committee}

B. Lourié (Editor-in-Chief), St. Pétersbourg

D. Nosnitsin (Secretary), Hamburg

D. Kashtanov, Moscow

S. Mikheev, Moscow

A. Orlov, Milwaukee

T. Senina, St. Pétersbourg

D. Y. Shapira, Jérusalem

S. Shoemaker, Oregon

\section{Secretariat}

T. Senina, St. Pétersbourg

E. Bormotova, Montréal

Scrinium. Revue de patrologie, d'hagiographie critique et d'histoire ecclésiastique, established in 2005, is an international multilingual scholarly series devoted to patristics, critical hagiography, and Church history. Each volume is dedicated to a theme in early church history, with a particular emphasis on Eastern Christianity, while not excluding developments in the western church. 


\title{
Symbola Caelestis
}

Le symbolisme liturgique et paraliturgique dans le monde chrétien

Edited by

\author{
Andrei Orlov
}

Basil Lourié

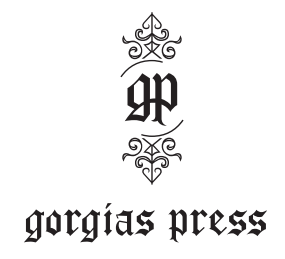

2009 
Gorgias Press LLC, 180 Centennial Ave., Piscataway, NJ, 08854, USA

www.gorgiaspress.com

Copyright (C) 2009 by Gorgias Press LLC

All rights reserved under International and Pan-American Copyright Conventions. No part of this publication may be reproduced, stored in a retrieval system or transmitted in any form or by any means, electronic, mechanical, photocopying, recording, scanning or otherwise without the prior written permission of Gorgias Press LLC.

2009

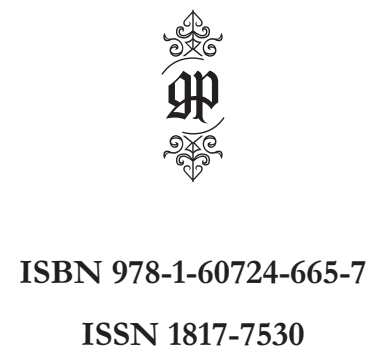

Printed in the United States of America 


\section{TABLE DES MATIÈRES}

Table des matières..................................................................................... vii

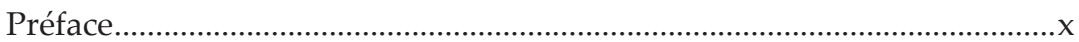

Liste des abbréviations ................................................................................

\section{Édition critique}

Andrei S. SlutsKiJ.

Early Slavonic Versions of the Liturgy of the Presanctified Gifts ........3

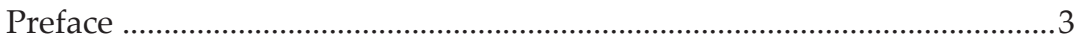

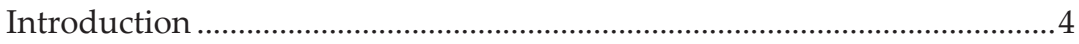

Manuscripts of the Old Russian Recension ..........................................12

Manuscripts of the Studite Recension ..................................................13

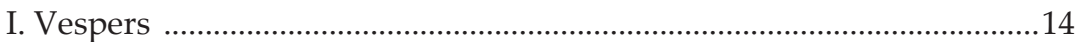

1. Structure of the Vespers of the Presanctified Liturgy

in the Manuscripts of the Old Russian Recension ................................14

2. Text of Vespers of the Liturgy of the Presanctified Gifts in the Manuscripts of the Old Russian Recension ...............................22

3. Manuscripts of the Studite Tradition ................................................25

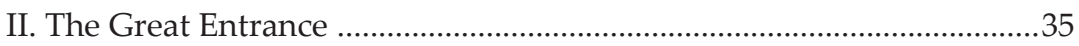

1. Liturgy of the Catechumens …..........................................................35

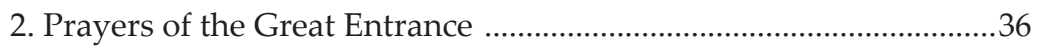

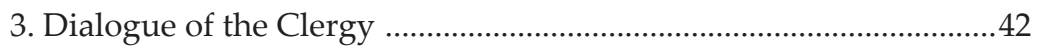

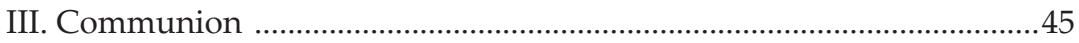

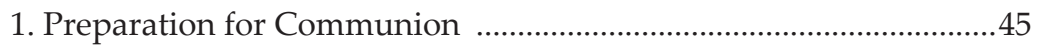

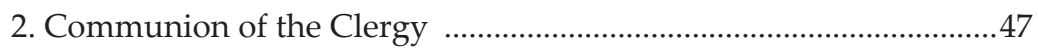

3. The Ending of the Service ...............................................................50

Appendix. Critical Edition of the Liturgy of the Presanctified Gifts in the Old Russian Recension ................................................................54 


\section{Articles}

Andrei A. OrLov. Eschatological Yom Kippur

in the Apocalypse of Abraham: Part I. The Scapegoat Ritual.

Silviu N. Bunta. "Your Own of Your Own":

Jewish Adam Speculations and Christian Liturgy

in the Slavonic and Romanian Life of Adam and Eve.

Bogdan G. Bucur. "The Mountain of the Lord": Sinai, Zion, and Eden in Byzantine Hymnographic Exegesis

Jack Custer. Inspired Word and Spiritual Worship:

How Byzantine Hymnography Interprets Sacred Scripture.

Stéphane Verhelst. Les prières de l'ambon

de la Liturgie de saint Jacques

Dmitrij F. Bumazhnov. Das Charisma in der christlichen Gnosis und im frühen ägyptischen Mönchtum.

Sung-Hyun Nam. L'Usage du Terme «notre père (пеNeIcUT) » dans la littérature pachômienne

Dragoş A. Giulea. The Heavenly Fire Working the Earth of the Heart: Origen, Antony, Pseudo-Macarius, and the Internalization of the Image of Divine Fire

Nestor Kavvadas. Theology of Language and Liturgical Prayer in Isaac of Nineveh.

Leena Mari Peltomaa. Role of the Virgin Mary at the Siege of Constantinople in 626.

Tatiana Borisova. To the Problem of the Reconstruction of the Early Stages of the History of the Church Slavonic Translation of the Akathistos Hymn

Tatiana A. SÉnina (moniale Kassia). Remarques sur le canon des défunts écrit par S. Cassia de Constantinople 
Youhanna Nessim Youssef. The Psalis

for the Consecration of the Church (Revisited).

323

\section{Notes}

Constanta Costea. Earlier Versions of Patriarch Germanus'

Homily on the Cross and the Icons

Vladimir A. Livšıc. Sogdian “Ancient Letters” (II, IV, V).

Basil Lourié. Courts of Solomon, A Jewish Collection

Basil Lourié. Slavonic Texts of Hard Fate: the Prophecy of Solomon and Some Others

Tatiana A. SÉninA (moniale Kassia). Un saint fouette un autre :

Théoktistos le logothète et Euthyme de Sardes

Youhanna Nessim Youssef. Two Notes on the Coptic Theotokias

\section{Bibliographie}

Michel Stavrou, Nicéphore Blemmydès, OEuvres théologiques.

Introduction, texte critique, traduction et notes. Tome 1 (B. Lourié) ......425

Tedros Abreha, Il Gädl di Abuna Demyanos santo eritreo (XIV/XV sec.).

Edizione del testo etiopico e traduzione italiana (A. Bausi)....

Nouvelles publications de l'Institut de la littérature russe

(Maison de Pouchkine) sur la littérature ancienne de la Russie

(B. Lourié) .436

Les publications récentes

dans la série $\Sigma \mathrm{MAPAГ} \triangle \mathrm{O} \Sigma$ ФI $\Lambda \mathrm{OKA} \Lambda \mathrm{IA} \Sigma$

Deux livres sur l'autocéphalie russe

Bibliographie du R. P. Michel van Esbroeck, s.j. Addenda. 


\section{Discussion}

Т. А. Вилкул. По поводу рецензии П. В. Аукина «Деконструкция деконструкции» [T. L. Vilkoul, À propos de la recension de P. V. Loukine «Déconstruction de la déconstruction»]

П. В. Дукин. Нужно ли нам «новаторство»?

(Об ответе Т. А. Вилкул)

[P. V. Loukine, Avons-nous besoin de l'esprit novateur?] 


\section{PRÉFACE}

La liturgie, c'est pour les liturgistes. Oui, il est vrai, mais ce n'est pas la vérité toute entière. L'intérêt scientifique des matières liturgiques ne se limite pas à l'histoire de la liturgie au sens strict. Il y a d'autres domaines où la compréhension de la liturgie est vitale même dans ses détails techniques. Tout d'abord, ce sont les visions mystiques du Temple céleste. Les apocalypses juives et chrétiennes aussi bien que l'expérience de la vie monastique du christianisme médiéval ouvrent des scènes de services dans le Temple céleste, devant le Trône de Dieu, dans l'entourage des anges et des esprits des justes. Parfois c'est uniquement l'analyse des données liturgiques qui serait capable de fournir la clef aux chiffres symboliques des textes mystiques anciens. D'ailleurs, la liturgie est toujours unie avec les traditions hagiographiques et artistiques. De temps en temps, des textes hymnographiques sauraient jeter de la lumière sur les faits historiques.

Telles sont, en bref, les idées sous-jacentes à l'approche interdisciplinaire qui a produit le recueil présent. Il contient des publications liturgiques sensu stricto aussi bien que des études dans les domaines où l'on fait usage du symbolisme liturgique.

Dieu voulant, ce ne sera que le début d'une file de publications où les liens entre la liturgie historique « pure » et ce que l'on peut nommer « la liturgie historique appliquée » seront de plus en plus étroits.

Andrei Orlov Basile Lourié 


\section{LISTE DES ABBRÉVIATIONS}

$B B$

ПСР $\Lambda$

ТОДРА

$X B$

$B B G G$

BHG

$B N$

$B S A$

$B S A C$

$B S a c$

$C B Q$

CBQMS

CFHB

$\mathrm{CSCO}$

ConBOT

CPG

DOP

GOTR

HTR

HUCA

$J B L$

JSJ

JSP

JSPSS

JTS

LIDDELL-SCOTT

NT

OC

OCP

$P O$
Византийский временник

Полное собрание русских иетописей

Труды Отдела древнерусской литературы

Христианский Восток

Bollettino dela Badia Greca di Grottaferrata

F. Halkin, Bibliotheca Hagiographica Graeca, vol. I-III (Bruxelles, 1957) (Subsidia Hagiographica, 8a)

Biblische Notizen

Bulletin de la Société d'Archéologie

Bulletin de la Société d'Archéologie Copte

Biblica Sacra

Catholic Biblical Quarterly

The Catholic Biblical Quarterly Monograph Series

Corpus Fontium Historiae Byzantinae

Corpus Scriptorum Christianorum Orientalium

Coniectanea Biblica. Old Testament Series

M. GeErard, Clavis Patrum Graecorum (Turnhout: Brepols) I (1973), II (1974), III (1979), IV (1980), Supplementum (1998) (Corpus Christianorum)

Dumbarton Oaks Papers

Greek Orthodox Theological Review

Harvard Theological Review

Hebrew Union College Annual

Journal of Biblical Literature

Journal for the Study of Judaism

Journal for the Study of the Pseudepigrapha

Journal for the Study of the Pseudepigrapha: Supplement Series

Journal of Theological Studies

H. G. Liddell, R. Scott (revised by H. S. Jones and

R. McKenzie), A Greek-English Lexicon (Oxford, 1968)

Novum Testamentum

Oriens Christianus

Orientalia Christiana Periodica

Patrologia Orientalis 
PG

PTS

SBLDS

SBLEJL

SBLSP

SC

$\mathrm{Scr}$

$\mathrm{SH}$

SJLA

SJSJ

SP

SVTQ

TCS

TLG

TSAJ

UBL

VC

WMANT

WUNT

ZAW

ZDMG

ZDPV
J. P. Migne (acc.), Patrologiae cursus completus. Series graeca, vol. 1-161 (Parisiis, 1857-1866)

Patristische Texte und Studien

Society of Biblical Literature Dissertation Series

Society of Biblical Literature Early Judaism and its Literature

Society of Biblical Literature Seminar Papers

Sources Chrétiennes

Scrinium

T. 2 (2006) - A. Mouraviev, B. Lourié (eds.), Universum Hagiographicum. Mémorial R. P. Michel van Esbroeck, s.j. (1934-2003)

T. 3 (2007) - B. LouriÉ, A. Orlov (eds.), The Theophaneia School: Jewish Roots of Eastern Christian Mysticism

T. 4 (2008) - V. Baranov, B. Lourié (eds.), Patrologia Pacifica. Selected papers presented to the Western Pacific Rim Patristics Society 3rd Annual Conference (Nagoya, Japan, September 29 -October 1, 2006) and other patristic studies

Subsidia Hagiographica

Studies in Judaism in Late Antiquity

Supplements to the Journal for the Study of Judaism

Studia Patristica

St. Vladimir's Theological Quarterly

Text-Critical Studies

Thesaurus Linguae Graecae (http://www.tlg.uci.edu/)

Texte und Studien zum antiken Judentum

Ugaritisch-Biblische Literatur

Vigiliae Christianae

Wissenschaftliche Monographien zum Alten und Neuen Testament

Wissenschaftliche Untersuchungen zum Neuen Testament

Zeitschrift fur die alttestamentliche Wissenschaft

Zeitschrift der deutschen morgenländischen Gesellschaft

Zeitschrift des deutschen Palästina-Vereins 